\title{
A Neogene deep-sea temperature record from clumped isotopes of benthic foraminifera from Walvis Ridge
}

\author{
ILJA JAPHIR KOCKEN ${ }^{1}$, JING LYU ${ }^{1}$, ROBIN \\ VORSSELMANS $^{2}$, BIANCA R. SPIERING ${ }^{1}$, WOUTER \\ STOUTHAMER $^{1}$, NOA J. BODE ${ }^{1}$, LARS VAN DUIN ${ }^{1}$, NIELS \\ M. VAN DE POL ${ }^{1}$, ANNE VAN DER MEER ${ }^{1}$, INIGO A \\ MÜLLER $^{1}$, LUCAS J. LOURENS ${ }^{1}$ AND MARTIN ZIEGLER ${ }^{1}$ \\ ${ }^{1}$ Utrecht University \\ ${ }^{2} \mathrm{KU}$ Leuven \\ Presenting Author: i.j.kocken@uu.nl
}

Neogene climate on Earth changed dramatically from an Antarctic ice sheet in its infancy to a warm phase during the Miocene Climate Optimum ( $14 \mathrm{Ma})$, followed by long-term transient global cooling, which culminated in Northern hemisphere glaciation and several glacials. The basis for most of what we know about long-term global climate is derived from long, multi-site composite $\delta^{18} \mathrm{O}$ records from benthic foraminifera [1-3].

One of the main problems with the $\delta^{18} \mathrm{O}$ proxy, however, is that it depends not only on the formation temperature of the calcite (cc) of the foraminiferal test, but also on the isotopic composition of the fluid source, in this case the seawater (sw). This means that changes to the $\delta^{18} \mathrm{O}_{\mathrm{sw}}$ - which is influenced by the precipitation/evaporation balance and thus salinity, as well as land ice-volume and oceanography_can mask changes in temperature.

In this study, we use the clumped isotope proxy $\left(\Delta_{47}\right)$ to provide independent temperature constraints that are based on thermodynamic principles. Clumped isotopes are measured simultaneously to the $\delta^{18} \mathrm{O}_{\mathrm{cc}}$ and enable determination of the $\delta^{18} \mathrm{O}_{\mathrm{sw}}$ that the foraminifera dwelled in.

We reconstruct deep sea temperatures from $\sim 20$ Ma to the present by applying clumped isotope measurements to wellpreserved benthic foraminifera from Walvis Ridge IODP Site 1264 sediments. Our novel measurements reveal warmer temperatures than traditional oxygen isotope thermometry studies, which is in agreement with recent $\Delta_{47}$ temperature reconstructions from the Indian Ocean[4] and the Southern Ocean[5]. These new findings show further evidence that previous estimates of $\delta^{18} \mathrm{O}_{\mathrm{sw}}$ during the Neogene may be flawed, hampering accurate temperature reconstructions solely based on the foraminifera $\delta^{18} \mathrm{O}_{\mathrm{cc}}$. Clumped isotope temperatures allow us to convert assumptions about $\delta^{18} \mathrm{O}_{\mathrm{sw}}$ into measurement-based estimates through time.

[1]: Zachos et al. (2001), Science 292(5517), 686-693.

[2]: Zachos, Dickens \& Zeebe (2008), Nature 451(7176), 279 283.

[3]: Westerhold et al. (2020), Science 369(6509), 1383-1387.

[4]: Modestou et al. (2020), Paleoceanography and Paleoclimatology, 2020-003927 (2020).

[5]: Leutert et al. (2020), Climate of the Past Discussions, 1-26. 